\title{
Article \\ "Maybe Jesus Was Suicidal Too": A United Church of Christ Pastor Reflects on His Suicide Attempt
}

\author{
Elizabeth Ryan Hall
}

Citation: Hall, Elizabeth Ryan. 2021 "Maybe Jesus Was Suicidal Too": A United Church of Christ Pastor Reflects on His Suicide Attempt. Religions 12: 930. https://doi.org/ $10.3390 /$ rel12110930

Academic Editor: Curtis Lehmann

Received: 17 August 2021

Accepted: 12 October 2021

Published: 26 October 202

Publisher's Note: MDPI stays neutral with regard to jurisdictional claims in published maps and institutional affiliations.

Copyright: (C) 2021 by the author. Licensee MDPI, Basel, Switzerland. This article is an open access article distributed under the terms and conditions of the Creative Commons Attribution (CC BY) license (https:/ / creativecommons.org/licenses/by/ $4.0 /)$.
University of Denver and Iliff School of Theology Joint Doctoral Program, Denver, CO 80210, USA; hall.elizabeth@spcollege.edu

\begin{abstract}
Research has long demonstrated that people who are religiously involved tend to be more shielded from suicide than those who are not, yet it has been less attentive to the conditions under which religiosity fails to inhibit suicidality. Since Durkheim's 1897 Suicide investigated the link between religious affiliation and suicide rates, most of the related research has also taken a broadscale sociological approach, used simplistic measures of religiosity, and ignored spirituality. Virtually absent are more penetrating idiographic investigations into suicidal individuals' lived experiences of religion and spirituality. This article aims to rectify that by presenting a qualitative study of eight suicide attempt survivors in the US. The complex convergences of religion/spirituality and suicidality in their lives are discussed. Religion and spirituality did palliate the participants' suicidality, but only after their suicide attempts; prior to the attempts, religious factors aggravated and even induced suicidal urges. During the suicide attempts, meanwhile, religion and spirituality were inconsequential. The story of one participant, an ordained minister in the United Church of Christ, is highlighted to illustrate the findings. Recommendations for further research and suggestions for spiritually integrated approaches to care encounters with suicidal individuals are given.
\end{abstract}

Keywords: suicide; religion; spirituality; suicide attempt; qualitative; suicidology; psychology

\section{Introduction}

Suicide is a pernicious and pervasive public health problem, with over 700,000 deaths by suicide worldwide in 2019 (WHO 2021), or one person every 40 seconds (WHO 2019). For every person who dies by suicide, many more attempt to kill themselves-in the United States, there are 25 suicide attempts for every suicide death (AAS 2021) —and for every person who attempts suicide, far more seriously contemplate doing so (Borges et al. 2010; CDC 2021). Each of these human beings was likely experiencing unspeakable emotional pain, or "psychache," at the time of their ideation, attempt, or death (Shneidman 1993). In addition, an estimated 135 people are exposed to-thus, affected by-each suicide (Cerel et al. 2019). The amount of despair and bereavement associated with suicide, then, is staggering. In short, suicide is a heart-wrenching phenomenon that touches almost everyone on earth.

In response to the grievousness of suicide, a formal discipline dedicated to the study of suicide, named "suicidology" by its progenitor, Edwin Shneidman, arose in the US in the 1950s, in the aftermath of World War II (Shore 2007). Drawing from a range of fields but especially psychiatry, psychology, and sociology (D. Webb n.d.), suicidology has advanced understanding and awareness of suicide and pioneered prevention, intervention, and "postvention" strategies while also exposing and challenging suicide-related stigma.

Despite the steady growth of the field and the prodigious literature it has generated, one topic received scant attention by suicidologists for the first 50 years: religion, along with religion's conceptual sibling, spirituality. For suicidology to have grown up, so to speak, in America but to overlook religion is surprising given how religious Americans are, relative to people in other wealthy Western democracies (Fahmy 2018). A likely reason for the dearth of research is the extraordinary popularity of Émile Durkheim's 1897 Suicide: 
A Study in Sociology, which investigated the suicide rates of Protestants versus Catholics and Jews in Western Europe and advanced the notion that the degrees to which people are integrated into and morally regulated by society determine how protected they are from suicide (Durkheim [1897] 1951). So embraced was this theory that even 75 years later, it would be called sociology's "one law" (Stack 1983; Stack and Kposowa 2011). The little research that was done on suicide and religion was almost exclusively sociological as well and tended to be simply an extension of Durkheim's work. The psychological aspects of suicide as it relates to religion, meanwhile, were virtually ignored (Dein 2005).

Just how meager suicidology's output was when it came to religion became evident when the Comprehensive Textbook of Suicidology was published in 2000. The authors devote only five of the book's 600 pages to religion. They state, "Usually, being religious tends to protect people from suicide ... Unfortunately, there are few empirical data on religion and suicide" (Maris et al. 2000, pp. 469-70). Although relevant studies began to appear in earnest in the subsequent decade, they largely relied on deficient methodologies given the complex nature of the subject. In 2012, distinguished suicide prevention researcher Erminia Colucci would sum up the problem in this manner:

The studies have typically been restricted to the analysis of the relationship between religiosity (often operationalized as church affiliation or attendance) and suicidal ideation/attitude or suicide mortality statistics. Very rarely have researchers addressed non-religious form[s] of spirituality or used a qualitative methodology. The picture ... becomes even more disappointing when we note that the findings about the influence of religion on suicide are inconsistent and ambiguous. (Colucci 2012, p. 78)

The tide finally turned about 10 years ago, when research began to feature more discriminating constructs of religiosity and suicidality ${ }^{1}$ (Gearing and Alonzo 2018; Jongkind et al. 2019; Lester 2000; Stack and Kposowa 2011; Stack and Laubepin 2019), consider spirituality $^{2}$ (Gearing and Alonzo 2018; Koenig et al. 2012; Kopacz 2015; Kopacz et al. 2014; Swinton 2001), and include qualitative designs (Hjelmeland and Knizek 2010; Kral et al. 2012; White 2016; Wittkowski et al. 2015). This more sophisticated research unambiguously points to the same conclusion arrived at by the Textbook authors in 2000—religion and spirituality are negatively correlated with suicide- - but also reveals qualifications hitherto unknown by suicidologists. The protective effect of religiosity/spirituality, it turns out, is strongest when it comes to deaths by suicide but is weaker with respect to suicide attempts and even weaker with respect to suicide ideation (e.g., Lawrence et al. 2016). The effectiveness varies according to people's gender, age, ethnicity, sexual orientation, religious denomination or sect, and psychiatric diagnostic category (e.g., Gearing and Alonzo 2018). In addition, crucially, religiosity/spirituality has the potential to be harmful, such as by contributing to a person's distress rather than relieving it (e.g., Blosnich et al. 2020).

A discussion of all the ways that religion and spirituality prevent or temper suicidality is beyond the scope of this article (see Hall 2017 for a detailed survey of the pertinent research from 1879 to 2016). Psychiatrist Harold Koenig, an authority on the effects of religion and spirituality on health, offers this concise summary of the main mechanisms by which they do so:

All major world religions forbid suicide that is carried out for personal reasons, although they vary in the intensity and circumstances for that condemnation. In addition, religion often surrounds the person with a supportive community, enables him or her to cope better with stress, and often protects against depression, substance abuse, and social isolation, major risk factors for suicide. (Koenig et al. 2012, p. 190)

As for the ways that religion and spirituality can fail to block suicidality or can exacerbate, encourage, or even cause suicidality, the growing number of studies that demonstrate this result suggest the following as the major contributing factors: 
- A failed, nonexistent, or antagonistic relationship with a religious community (Colucci and Martin 2008; Lawrence et al. 2016; Nelson et al. 2012; Park and Slattery 2013);

- A religious tradition that is judgmental, moralistic, or ostracizing (Bryan et al. 2015; Gibbs and Goldbach 2015; Lytle et al. 2018);

- A belief that one is being punished, oppressed, betrayed, or deserted by God (Bryan et al. 2015; Colucci 2008; Jongkind et al. 2019; Lawrence et al. 2016; Smigelsky et al. 2020; Swinton 2001);

- Irreconcilable anger toward God or questioning of God (Baetz and Bowen 2011);

- A discrepancy between one's beliefs and the teachings of one's religious tradition or the sense that one is failing to live up to the tradition's standards (Rickgarn 1990);

- Other religious/spiritual struggles as defined by the Religious and Spiritual Struggles Scale (Currier et al. 2018; Exline et al. 2014; McGraw 2020; Raines et al. 2020);

- Negative religious/spiritual coping (Currier et al. 2017; Dua et al. 2021; Goodwin 2013; Prempeh 2013; Rosmarin et al. 2013; Shannonhouse et al. 2020);

- A lack of meaning or purpose, when characterized as a spiritual problem (Colucci 2008; Knizek et al. 2021; Smigelsky et al. 2020);

- A belief in metempsychosis (reincarnation) or an afterlife that is preferable to the current life ${ }^{3}$ (Zhang and Xu 2007).

Despite- or perhaps because of - this recent proliferation of scholarship, many questions have yet to be answered. The subtler junctions between suicidality and religiosity/spirituality are only starting to be explored, especially with respect to the ways the latter does not protect people from wishing to end their lives. Penetrating psychological investigations into suicidal individuals' lived experiences of religion and spirituality-highly personal, idiosyncratic phenomena whose nuances are often flattened in research-are still rare.

The purpose of this article is to present such an investigation. The author conducted a qualitative study with the hypothesis that religion and spirituality can have both palliative and malignant effects on a person's suicidality. The focus was "not whether religion and spirituality are good or bad, but rather when, how, and why they take constructive or destructive forms" (Pargament et al. 2013b, p. 7; italics in the original). The central research question was "What experiences have suicide attempters had with religion and spirituality over the course of their lives?" Eight individuals who have attempted suicide described these experiences in in-depth, semi-structured interviews. The narrative of one of them will be elaborated upon here.

\section{Materials and Methods}

\subsection{Rationale for a Qualitative Approach}

To ascertain how religion and spirituality have interacted with the suicidality of suicide attempt survivors, the author, henceforth referred to as "I,"4 opted to target the survivors' "lived religion," the "ever-changing, multifaceted, often messy-even contradictoryamalgam of beliefs and practices" one espouses both inside and outside the walls of a religious institution (McGuire 2008, p. 4). I also wished to spotlight their lived spiritualitythat is, how they experience sacredness in their daily lives. Thus, I needed a research framework that could make room for both the nebulous and the numinous. Qualitative was the obvious choice.

Nearly all the extant suicidological research pertaining to religion/spirituality is quantitative. "One of the limits shown by quantitative studies of religion," writes Colucci, "is that usually they are reductionist, simplistic and treat religion and spirituality as if they are unidimensional constructs, often assuming that these can be adequately measured by a single variable" (Colucci 2008, p. 88). Sociologist of religion Nancy Ammerman, who conducted an extensive qualitative study on "everyday religion," makes a similar point: "Religiosity in practice does not neatly conform to the survey questions with which we have tried to explain religion's presence or absence, rise or decline" (Ammerman 2014, p. 6). Thus, to elicit her study participants' lived religion and spirituality, she and her 
team asked creative interview questions meant to avoid the "hegemonic cultural scripts for how one speaks of religion" (Ammerman 2014, p. 15). For instance, "rather than asking them how much their faith influences their lives, we asked them to tell us about a time when they made an important decision, and we simply listened for whether and how faith was invoked" (Ammerman 2014, p. 14). This interviewing style made sense to me not only as a researcher but also as a professional counselor used to asking people probing personal questions. I chose the qualitative paradigm, then, because it would enable me to use unconventional questions such as these to access the richness of my study participants' lived religion and spirituality. It would also permit me to convey this richness in writing by using "thick description" (Geertz 1973) in my report, which is the custom, if not the duty, in qualitative research.

Compared to a quantitative approach, a qualitative one would also better suit my purpose of examining individuals' psychology of suicide. Like religion, suicide has historically been studied more often in "size-oriented" than "depth-oriented" ways (Colucci 2013, p. 37); that is, the research has tended to rely on larger sample sizes without plumbing the idiomatic psychological facets of suicidality. The former mode of inquiry seeks explanation, while the latter seeks understanding (Hjelmeland and Knizek 2010, 2011). While both modes are important in suicidology, explanation-focused studies, especially causal explanation, have long dominated the field (Hjelmeland 2013; Hjelmeland and Knizek 2010, 2011, 2016). A depth-oriented approach could lead to new discoveries and, in turn, shape new lifesaving intervention strategies. As psychologist James Hillman puts it in Suicide and the Soul, "In order to get closer to the problem of suicide, we first try to understand the life of the individual whose death is involved. We begin with an individual, not with the concept" (Hillman [1965] 2011, p. 51).

In addition, in opting for a qualitative methodology, I would have the support of an increasing number of scholars who recognize its potential to capture elaborate or recondite phenomena that elude easy measurement (e.g., Pargament et al. 2013c; Plöderl et al. 2020). Incidentally, a 2016 meta-review on religion and suicide risk calls for precisely the research I aimed to carry out in this present endeavor: "Qualitative studies might ask participants about their religious involvement specifically during periods of suicidal ideation ... Both suicide risk and some religious characteristics (e.g., feeling close to God) can change over time, and researchers have yet to ask participants 'In the moment when you were acutely suicidal, what was the role of religion'” (Lawrence et al. 2016, p. 16)?

\subsection{Sampling, Recruitment, and Data Collection}

The specific qualitative method I chose for my study was a blend of phenomenological and narrative styles (see Hall 2017 for a more detailed explanation of my methodology). I sought as participants five to eight adults with a history of suicide attempts. My strategy for finding eligible participants was criterion sampling (Bloomberg and Volpe 2012; Creswell 2013). In phenomenological research, the "criterion" is experience with a particular phenomenon; in this case, the phenomenon would be one or more suicide attempts in one's life rather than involvement with a particular religious tradition or in fact with any religion at all. Once the University of Denver's Institutional Review Board (IRB) approved my study, I disseminated recruitment flyers. Within a few weeks, 10 volunteers across the US had contacted me. All met the eligibility criteria except for two who lived prohibitively far away, so I accepted the eight who were geographically accessible.

I met with each participant one-on-one in a private setting. After giving their informed consent, they filled out a 2-page questionnaire about demographics (see Table 1), history of suicidal behavior, current thoughts or plans of suicide (being currently suicidal would disqualify them from participation), whether they were working with a mental health professional, and emergency contact information or instructions on what I should do if they felt distressed during our talk. I also had them give themselves a pseudonym. 
Table 1. Participants' demographics.

\begin{tabular}{|c|c|c|c|c|c|c|c|}
\hline Pseudonym & Gender & Age & Race & Education & Occupation & Marital Status & Religious Affiliation \\
\hline Abby & $\mathrm{F}$ & 45 & W & Master's & Epidemiologist & Married & "Catholic (lapsed)" \\
\hline Deacon & M & 39 & W & Some college & $\begin{array}{l}\text { Emergency medical } \\
\text { technician and critical } \\
\text { care technician }\end{array}$ & Married & “None" \\
\hline Elizabeth & $\mathrm{F}$ & 58 & $\mathrm{~W}$ & Master's & $\begin{array}{c}\text { Educator/advocate/ } \\
\text { consultant }\end{array}$ & Widowed & $\begin{array}{l}\text { "Culturally } \\
\text { Christian/ } \\
\text { Ideologically } \\
\text { Buddhist" }\end{array}$ \\
\hline Gabriela & $\mathrm{F}$ & 40 & W & Master's & Advocate/writer & Divorced & Buddhist \\
\hline Harrison & M & 48 & $\mathrm{~W}$ & Master's & Social worker & Married & "Roman Catholic" \\
\hline Jeremy & M & 33 & W & Master's & Hospital chaplain & Married & $\begin{array}{l}\text { "United Church of } \\
\text { Christ (Christian/ } \\
\text { Protestant/liberal)" }\end{array}$ \\
\hline Phil & M & 51 & $\mathrm{~W}$ & $\begin{array}{l}\text { Master's plus } \\
\text { PsyS }\end{array}$ & $\begin{array}{l}\text { School psychologist } \\
\text { and adjunct professor } \\
\text { of psychology }\end{array}$ & Married & $\begin{array}{l}\text { "Christian (non- } \\
\text { denominational)" }\end{array}$ \\
\hline Stern & M & 29 & W & Some college & $\begin{array}{l}\text { Volunteer at mental } \\
\text { health nonprofit }\end{array}$ & Single & "Universalist" \\
\hline
\end{tabular}

Then, we commenced the semi-structured interview. The goal was to elicit the participants' accounts of the experiences they had had with religion/spirituality before, during, and after their suicide attempt(s). I relied on a script as a loose guide to ensure that I asked each person the same general questions, but I wanted the conversation to flow naturally and rapport to be maximized. The questions were designed to accommodate a broad range of past and present experiences, including the absence of a religious/spiritual background. The following is a selection of the prompts:

- You wrote on the questionnaire that as you were growing up, your family was affiliated with the __ tradition. Tell me more about your involvement with that tradition. If no tradition: What exposure to religion or spirituality did you have?

- What did "God" mean to you when you were growing up? How have your beliefs about God/___ (use participant's preferred term) or your relationship with God/___ changed over time?

- Would you say you have experienced religious or spiritual struggles? Please describe them and how they have affected your life.

- You wrote that you were ___ years old when you (first) attempted suicide. What role, if any, did your religious/spiritual beliefs or practices play in your life at that time or in your intention to end your life?

- Tell me about religion/spirituality in your life today.

Although the questionnaire addressed respondents' prior and current suicidality, per IRB requirements, no questions from the interview proper probed for details about their suicide attempts. Every participant, however, voluntarily talked about his or her attempt. As a result of the first interviewee's doing so, which included his thoughts on why he survived, I added the question "To what do you attribute the fact that you survived your suicide attempt?" to the script. It ended up educing as much insight into each person's spirituality as the questions patently about that topic.

The meetings, which occurred between November 2015 and January 2016, lasted an average of $95 \mathrm{~min}$. Although the interviewees had the option to skip any questions they did not wish to answer, all answered every question, seemingly without qualms. None exhibited distress or required psychotherapeutic intervention. In fact, each of them mentioned afterwards that they enjoyed the interview or were pleased to be in the study.

I conducted follow-up interviews with "Jeremy," the participant highlighted in this article, by telephone in December 2020 and July and August 2021 to update my findings 
with respect to religion and spirituality in his life today and explore his relationship with religion-based suicide stigma. He read and approved the article draft.

\subsection{Data Synthesis and Analysis}

First, I transcribed the audio-recorded interviews. Then, using techniques described by Bloomberg and Volpe (2012) and Creswell (2013), I carried out rigorous semantic coding procedures on the transcripts with continual checking of my work, keeping notes and "memos" (observations, decisions, and questions related to the process and content of the data collection and analysis) all the while. I organized the data into the following categories based on my interview questions: history of religion/spirituality (RS), definition of RS, God, RS struggles, RS today, RS practices, suicide story, why lived, suicide as option, and miscellaneous. Eventually, themes and patterns in the data emerged.

To enhance readers' understanding of the phenomenon and maximize the "trustworthiness," "credibility," and "transferability" of their work-the qualitative research counterpart to quantitative research's validity, reliability, and generalizability (Bloomberg and Volpe 2012) — qualitative researchers include in their report many quotations from their participants, and I will do the same here.

\section{Results}

Because telling all eight participants' stories would be too lengthy for this article, I will rely on the story of one, Jeremy, to illustrate this study's findings. I have chosen his story for three reasons: (1) it exemplifies every theme that emerged when I carried out my coding and thematic analysis; (2) he is affiliated with Christianity, the religious affiliation of a third of the world's population (Pew Research Center 2011), so I thought his story would have broad appeal; (3) he is articulate and highly self-aware and, therefore, especially quotable. Readers are invited to refer to Hall 2017 for the rest of the narratives.

\subsection{Religion and Spirituality before the Suicide Attempt}

Jeremy is a White, heterosexual, married man with a Master of Divinity degree. He was 33 at the time of the interview (6 January 2016) and grew up in the Mountain West region of the US.

The year Jeremy was born, his "spiritual but not particularly religious," scientifically minded parents had moved to a new state and decided that "going to church was an important part of raising kids." They put a lot of care into finding a church with a theology that "felt right," eventually settling on one within the United Church of Christ (UCC) denomination. Even though the church was located a 45-min drive from their house, the family attended every Sunday. Jeremy recalls "running around the church [and] crawling under the pews during worship, scaring people" as a child. It was the setting for countless cherished memories: being baptized with his brothers, receiving his first Bible when he was in third grade, being taught by "lots of wonderful teachers" in Sunday school, and avidly participating in youth group. "I have an intimate, close relationship with that particular congregation," he said.

Jeremy's home life changed drastically when he was in middle school. His dad attempted suicide twice and his parents' marriage dissolved. Jeremy took solace in the church. He explained, "I spent a lot of time struggling with what love meant and yearning to be loved in a way that I saw, or perceived that I saw, other families love each other. Being at the church offered me love in a way that I didn't find at home; at home was often very stressful."

He further immersed himself in the church when he took confirmation classes, which he "loved so much ... That was a time in my life that I was ready to learn a lot more about God and wrestle with some of the bigger issues." At the end of confirmation, he was invited to preach the Father's Day sermon with his confirmation mentor. It was well received; "a lot of people gave me a lot of affirmation." All this positive attention was a balm for a melancholy teen. When a church member sent Jeremy a letter encouraging 
him to become a minister, he listened. He joined a church committee, volunteered at a UCC summer camp, served as a youth group leader, attended a UCC college, and took a leadership position at a local UCC church. For him, the UCC is "a place of home and belonging."

In college, Jeremy attended an evangelical church for a few months to check out a denomination with a different theological stance. That combined with another experience would teach him that his optimum theological environment is a progressive one. As a fresh college graduate, at the behest of the UCC conference, he served as temporary minister for a church in a "tough" frontier town that was between pastors. Although he is proud of his work "help[ing] a dying church not die," Jeremy found himself at odds with the popular ideologies there. He said:

What it did was it amplified all these liberal theological ideas in me, because I was like, "No, that's not who God is!" I would go to these clergy meetings with evangelical and other Protestant ministers who would talk about crazy theological crap (laughs). I'd be screaming in my head, "Aaaaah! What am I doing here? This is not the Church; this is not what I believe Jesus-God-is about." So, it really made me stand up and take some more vocal action about social justice.

The UCC church of Jeremy's childhood took notice of the work he was doing and offered him a job as youth director. He accepted and relocated again. Initially, it was "refreshing and wonderful" to be back in his "spiritual home," but after about a year, "things emotionally for me really began to unravel."

\subsection{Factors Contributing to the Suicide Attempt}

\subsubsection{Feeling Trivialized}

Several relationships in Jeremy's life in the months leading up to his suicide attempt contributed to a sense of being invalidated and alienated. First, "well over half the congregation" at his childhood church, where he was now employed, not only remembered him as a "youngster" but also responded to him as one. "I'd be trying to offer them spiritual care," he explained, "and these were people who, like, saw me run around in diapers. I felt like I wasn't taken seriously ... and that I could never get beyond that [perception of me]." Second, the office secretary, whom Jeremy considered a friend, began to say sexually suggestive comments to him, which made him uncomfortable. Confronting the man about it and eventually meeting with senior personnel proved fruitless. "I got to the point where I felt like was having to sneak into the office just to do my work," he said. "I felt like I was dismissed. That was on top of not feeling like anyone actually respected me as a professional." Third, the woman Jeremy was dating "and thought I was falling in love with" revealed some troubling things about herself to him. Crestfallen, he realized that the differences in their values and plans for their relationship were irreconcilable. Sensing his increasing despondency, he went to his family members for comfort. They, too, downplayed his feelings and merely advised him to get on medication for depression.

It was dismissal from his psychotherapist, however, that would have the most disastrous consequences. When Jeremy was at work one day, his demoralization and psychological anguish peaked, and suicide was the only remedy he could conceive of. He called his therapist and told her of his plan to kill himself by overdose on pharmaceutical drugs, expecting that she would console him and revive his hope. She asked him to drive home, collect all his pills, and take them to her. His depression-addled mind could only produce one interpretation of this response: he had been blown off yet again; by failing to call the police and request a safety check or emergency hospitalization, his therapist was not taking his suicide threat seriously and was even disregarding him as a person. This slight was the last straw, the final sign that nothing would ever get better. Jeremy complied but only partially; he gave her less than half of the pills. After leading youth group that night, he went home and attempted to overdose on the remaining pills. 
Collectively, then, rather than providing Jeremy with the emotional sustenance he needed, these interactions with people important to him had exacerbated his sadness and his certitude that he did not belong in the world. "When I went to people to ask for help," he said, "I was like, 'Someone see me and acknowledge that this is happening,' and I felt like that wasn't there, ... like no one respected me. I was surrounded by people that I thought cared about me, but I felt like I was completely alone and isolated ... My heart and my spirit were broken."

\subsubsection{Intergenerational Depression and Suicidality}

While growing up, Jeremy witnessed his father endure bouts of debilitating depression, which culminated in two suicide attempts and a month in a psychiatric hospital when Jeremy was a preadolescent. In response,

the church took a huge step back from my dad ... I witnessed church members taking sides and being really supportive of my mom, which they should've, but my dad was kind of left out there high and dry. Over the course of a couple months, it was like my dad lost all his friends at the church ... He stopped coming to worship. He was never invited to the men's fellowship groups or anything like that. At the point at which my mom and dad divorced, my freshman year of high school, my dad couldn't walk into the church. He was not greeted by people, or if he was, it was a very awkward exchange.

Because Jeremy "loved and trusted" the other church members, he went along with what they did, rallying around his mother and regarding his father with disdain. He decided that his father "had done the worst thing in the world by attempting suicide and he was ruining our family life. I didn't have the language around mental health and I didn't see anyone in the church doing anything to help my dad, so ... I sided with the church and I sided with my mom."

Now, at age 27, Jeremy was working for the very church that had turned its back on his suicidal father years before, and he was feeling suicidal himself. He had experienced "these moments throughout my life where ... [I was] trying to figure out 'How do I make this sadness stop?'" His "strange dance with the history of depression in my family" manifested itself in a poignant experience over lunch one day. He had been having trouble making ends meet on the youth minister salary he was earning. More and more frequently, paying his bills meant having to skip meals, which he did not admit to anyone. One morning, sitting in the church office, Jeremy realized how little he had eaten in a few days. Terribly hungry and having no money for food, he slipped out of the office so he could get a free meal at a nearby charity organization. "It triggered a memory for me," Jeremy said. "For a time, my dad, after my parents' divorce, became homeless and lived at one of the homeless shelters in town. He picked [my brother and me] up from church and didn't have money for lunch, so he took us to the soup kitchen. We stood in line and got food and sat down." As adult Jeremy sat "at almost the exact same table as with my dad a decade before," he remembered how "embarrassed and ashamed" he had felt as a boy, eating among the needy. Crushing dismay followed as he reflected on how he, his family, and his church had treated his father after his father's suicide attempts. "Watching my dad just be cast away and lost from the church," he explained, "was trauma, and that trauma was being triggered within me."

\subsubsection{Despair and Cognitive Distortion}

In the weeks leading up to his suicide attempt, despair permeated Jeremy's psyche to such an extent that it colored all his perceptions. Visiting an art gallery and seeing a photograph of a crucifix in a garbage receptacle, watching a film about a professional wrestler past his prime-virtually everywhere he looked, including within, he saw suffering. He recalled:

I spent a couple weeks just eating with a bunch of homeless people and being like, "What is going on in my life where I can't afford to do this [pastoral] work?" 
and ... "I'm not good enough to go to seminary, but if I go to seminary I can be better at what I do"-just this internal wrestling ... I blamed God; like, "If God is good, and Jesus is good, then why do we live in a world that just hates so much? Why do I work in a church where no one respects me or appreciates me or validates me?"

Being "a minister who was charged with saving people from suffering" was becoming an unbearable responsibility; after all, Jeremy could not even save himself from suffering.

Irrational, often hyperbolic thinking reinforced Jeremy's emotional agony. His perception that he had been dismissed by the important people in his life, exaggerated by his mind, had turned into certainty that no one would ever care about him. His difficulty lifting his spirits had morphed into the belief that he would never be happy again. The more disconnected Jeremy felt from hope, joy, and others' goodwill, the more disconsolate he became. Doomed to suffer without reprieve. He was heading "down this very dark tunnel that was hard to see out of," and, as he saw it, the tunnel had only one exit. Only death would end the pain. "Any other solution seemed absurd to me," he stated. "The only reality I could think of at that moment was ending my own life. All these other options didn't feel real to me."

That other people might be hurt by his suicide did not occur to Jeremy. The cognitive distortion accompanying his profound dejection not only blocked out or nullified anything that used to cheer him up but also skewed his assessment of the impact of his death on others. In fact, he reasoned, if suicide could benefit him, why could it not benefit others as well? The suicidal person's rationale, he explained, is as follows:

"I'm taking myself out of your life so you don't have to worry and care for me. It's one less thing that is dragging you down, and now you can go live your life and be happy without me moping around and being sad"- - which, in the middle of you being very sad, makes complete sense. I remember writing a journal entry about how I felt like I just wanted to die, and the image of me being this ship-a sailing ship in the ocean: I would die, and the ship would sink into the ocean, and, resting on the bottom of the ocean, the ship was dead, but it brought forth more life. So, coral and fish began to live in the carcass of the ship at the bottom of the sea, and I was trying to describe how that was a very beautiful thing. Very poetic to me. Like, "If I killed myself, think of all the life that could emerge from that, all the opportunities for other people... Maybe I can teach these people something through this death."

Further pursuing this line of thinking, Jeremy was reminded of Jesus Christ, the central figure of his religion, and the circumstances surrounding Christ's death.

I was able to add that Christ story, the crucifixion, onto my own experience; like, "Well, maybe Jesus was suicidal too." I mean, he didn't stop! And look what it did for the world; ... in the midst of it happening, it didn't change the hearts of the people that were there, but [ultimately] it did! It taught people [that] here's a person who loved people so much he was willing to give up his life for them. And, in a way, I thought, "Well, maybe that's what I was trying to do." ... It was never thought out, during or before, that this was a religious act, but I think later, as I was reading some materials and hearing some authors talk about suicide as a salvific act, I kind of got this idea that, like [it was for] Jesus, you know, dying was an act of redemption.

\subsubsection{The Stigma of Suicide}

Four themes emerged in Jeremy's reflections on how he was affected by the stigmatization of suicide: silence, ostracism, shame, and distrust. "Silence" represents what his church communicated from the pulpit about suicide as he was growing up. Bible stories featuring suicide and suicide ideation were neither considered from a psychological perspective nor accompanied by a discussion about mental health in contemporary society or in the congregation specifically. Then there was the ambiguous nature of Jesus' death: as Jeremy put it, "the ultimate figure of the Christian Church is an example of willingly going 
to die. Is it martyrdom? Is it suicide? I don't know! But it's framed as this ultimate act that is glorious." The church did not clear up this issue for him but did make it clear that he, as a Christian, should emulate Christ. This was a confusing message for Jeremy when, as a boy, he began to experience depression and suicidal thoughts. His church provided no education, theological analysis, or emotional support.

Church members were equally mum, as was his family. Thus, when Jeremy's father attempted suicide, "my dad never talked about it, we as a family would never talk about it-and how could we? We had no knowledge or words to use. So, I was never able to process it and figure out what it meant for me." He suspects that this reticence concerning depression and suicide also contributed to his parents' divorce, a heartrending experience for his whole family. Mournfully, he noted, "My mom has told me that if she knew then what she knows now about depression, things may have been very different with her and my dad. An informed [and communicative] system of loved ones can make a world of difference."

The church's ostracism of Jeremy's father was what ultimately conveyed its stance on suicide to Jeremy. "The stigma around suicide was really a clear message to me," he said. "The action I saw the church take was clear support for my mother and abandonment of my dad." The suicide attempts and subsequent hospitalization had rendered Jeremy's father a pariah, and Jeremy had followed their example and shunned his father too. It would take Jeremy years to "get mad at the church" for its treatment of his father, to acknowledge his own role in it, and to "confront some of that unresolved grief that I had about that whole experience."

Meanwhile, Jeremy had learned that he needed to hide his own suicidal inclinations because he had seen what being suicidal had entailed for his father. He explained:

My perspective as a teenager was if you are depressed, or if you attempt suicide, the church will forget you ... And now here I am at 27, 10 years later, and I'm feeling sad and depressed and suicidal, and if I share that with the church, which is my safe place and my place of healing, it would ruin me! I would no longer have a safe place; I would no longer have a community that would care about me. They would all gasp and take a big step back. So that was the stigma that I felt working before [my] suicide attempt; it was "I don't know how to talk about this in my church. I can't talk about it."

Consequently, he $d i d n^{\prime} t$ talk about it, which, presumably, only worsened his alienation, despair, and the other factors fueling his urge to kill himself.

The psychospiritual effect the church's anathematizing of Jeremy's father had on Jeremy can be summed up in one word: "shame," a word he said no fewer than 24 times in three interviews. The church had taught him, implicitly, "suicide is an act of shame," a spiritual and moral blemish that taints those it touches. He felt tainted by his father's suicide attempts and then by his own suicidal tendencies, leading him to conclude "I could never be ordained in the church, having tried to kill myself or being depressed." His shame also stemmed from the notion that good Christians are not supposed to be suicidal. In Christian theology, he said, a single, eternal solution to despair is presented, "and that solution is to take Jesus as your savior and be free from it all. But the pain was that I did follow Jesus and I was-I felt like I was doing Christian work and that I had this strong belief, but it wasn't enough to protect me from depression and suicide."

Last, the stigma of suicide took the form of distrust by others, especially following Jeremy's suicide attempt. When his loved ones and employers found out that he had not only tried to kill himself but also "kept my depression a secret and didn't reach out to them in ways that they could have possibly helped," they treated him as untrustworthy. They rightly judged suicide a bad decision, said Jeremy, but were suspicious of him instead of empathetic like he needed them to be. "All of them, when I shared this," he explained, "treated me like I'd betrayed them in some way ... To me it felt confusing because I was trying to reach out and get help, ... but the experience I received back was 'You're not right in the head, so we can't trust that you're going to make rational decisions.'" Suicide stigma, 
it seems, had engendered misinformation and lack of understanding about suicide, which in turn engendered discrimination and uncompassionate responses from others. This was especially true when Jeremy was released from the hospital and his family members and supervisor insisted on checking on him regularly. "Rather than the experience of trust as surveillance," he said, "what I actually needed as a sense of trust was affirmation: 'I see you, I trust you, I love you.'"

One effect of others' distrust of him was distrust of himself, which took years to repair. A more lingering effect has been fear.

Fear still exists in me that I'm gonna tell this story and say something very personal about myself, and I don't know if that other person is going to want to trust me anymore. That means that [those of us who have been suicidal] don't want to share these experiences! We don't want to talk about suicide, we don't want to talk about depression. And I think that's why there's a lot of clergy who don't want to share the truth of their depression and suicidal idealization; it's because they will never be trusted again in the church.

Distrust, then, like silence, ostracism, and shaming, can perpetuate the stigma of suicide and, by extension, suicide itself.

\subsection{Why He Survived}

Jeremy's answer to the question "To what do you attribute the fact that you survived your suicide attempt?" was that something inside him turned on when he was faced with extinction. He explained, "99\% of me was like, 'I just-I need this to end. I need to stop suffering, and I wanna die.' And there was a small voice-maybe it was my [Jungian] shadow? Maybe it was something inside of me that just-a part of me that wanted to be seen and heard said, 'No, not yet.'" He described how, mid-suicide attempt, in his intoxicated stupor, he somehow located his cell phone, which he had hidden earlier so he could not access it, and called his therapist and told her what he had done. That call, to the very person who had seemingly disregarded him earlier in the day, ostensibly saved his life, as she contacted the emergency services personnel who took him to the hospital. However, it was something more arcane, the remaining $1 \%$ of himself, that had activated the will to live that resulted in the call. "I think that's what ultimately saved me," he said. "This part of me, the shadow part, was like, 'You're hurt, and you're wounded, and you're poor, and no one loves you' ... I wanted to cut the shadow out of me, even if it meant killing myself. I needed to be done with this dark part of me that was so unbearable and so suffering!"

When Jeremy heeded his shadow's cry to be illuminated, the part of himself that he found "unbearable" and worthy only of annihilation turned out to be his savior. His shadow, then, was simultaneously a source of woe and an agent of salvation, a reason to die and a reason to live. Paradoxically, by "embracing that part of me that hurts so much" instead of "cutting it out and dismissing it because it's causing so much pain," he found the key to surviving his suicide attempt and assuaging his psychache.

Bringing his shadow into the light has functioned not only as the cause of Jeremy's survival but also as the purpose of it. Over time, he began to share his suicide story with trusted others such as fellow chaplains. By "engaging and processing" that part of his past, he has come to see that "talking about suicide is actually healing," both for himself and for others. "When we bring light to that darkness," he said, "we actually help remove that commitment to want to kill yourself. It makes it harder to go there, because now someone sees you." Thus, Jeremy infuses his pastoral care today with the growth and learning that he has derived from surviving his suicide attempt. In an emulation of God as he sees God, he extends affirmation to others, "seeing" them and "hearing their story" - especially those attempting to snuff out their shadow. 


\subsection{Religion and Spirituality Since the Suicide Attempt}

When Jeremy woke up in the hospital after his overdose, he was furious that he had not died. The despair he felt prior to his suicide attempt had not only not subsided but also been supplemented by a torrent of nihilism:

I was like, "There is no God. There is nothing. There is no meaning or reason, and if I die it's just a body in the ground. And I don't have a soul or anything like that, because it doesn't mean anything! We're not even making sense when we talk about spirituality. There's no love and there's no real community that can support me." I was so, just, done. With the church, with God. I felt alone and abandoned. The meaning of life had been completely lost for me, and I was really struggling with that!

Jeremy's supervisor, the senior pastor of the church, came to visit him, yet the conversation they had only inflamed Jeremy's anger and sense of being discounted by others. As Jeremy remembers it, the pastor did not minister to his suffering; he only talked about how hurt he was that Jeremy had not confided in him about being suicidal. Being released from the hospital only brought with it the distrust and "surveillance" already described; Jeremy was still not deriving comfort from virtually anything. About two weeks after his suicide attempt, he had a distressing conversation with his ex-girlfriend. He walked out to his car, found a bottle of non-prescription painkillers, and ingested them.

Jeremy's literal awakening the next morning was also an existential one, the turning point in his life story. With chagrin, he reflected on his act of self-harm from the night before: not a full-blown suicide attempt, he decided, because he was not trying to die, but a "continuation of what I was feeling before, like tremors after an earthquake." Another protest against the harshness of the world. Enough was enough, he thought; taking his psychic pain out on himself had to stop. His psychic pain itself had to stop! Like an addict who had hit "rock bottom," he "had come to the most broken place" in his 27 years. Definitively, he declared, "I can't do this to myself anymore. I can't. I need to change." The changes he made as a result were sweeping and in quick succession: he quit his job at the church, applied for and was accepted by a seminary in another state, and took a seasonal job at the UCC summer camp that employed him when he was younger. The decision to return to the camp would prove to be momentous, as it was there, two months after his suicide attempt, that he met "Emma" (name changed by Jeremy), the woman who would help revitalize him-and become his wife.

Emma, herself about to head to seminary in another state, was not afraid to tackle tough theological issues with Jeremy, nor was she intimidated by "all these deep pains" that he was bearing. She listened to him and met him with understanding and acceptance, the opposite of the invalidation he had received from so many others prior to his suicide attempt. Jeremy finally felt seen and heard. As their relationship matured, Emma's steadfast care for him prompted a substantial change in his worldview and theology. The conception he had of God, he realized, was not favorable, helpful, or applicable to his life- to the extent that one day, he told Emma that he was not sure he even believed in God. The "amazing heart-to-heart conversation" that ensued paved the way for years of collaborative "rebuilding and reconstructing [of] God in a way that was meaningful for both of us." This reconceived God, inspired by Jeremy's experience of boundless love from Emma, was pure affirmation, "that thing that says yes in the universe, that doesn't dismiss, that doesn't ignore who we are but calls it forth from us." The shame he had internalized, the stigma of suicide, the pain of rejection and self-doubt: each was wiped away by this force of radical acceptance.

As Emma was resuscitating Jeremy's spirit and helping him refashion his personal faith, another person was helping him reimagine his identity as a clergyperson: Anton Boisen, pioneer of clinical pastoral education, whose writing Jeremy encountered while working on his Master of Divinity. Boisen, who had schizophrenia, was not only open about his ordeals with psychosis but even wove them into his approach to chaplaincy. He 
argued that far from being separate entities, his religiosity and mental illness were, in fact, intertwined. "Why it was eye-opening for me," Jeremy said,

is that for years I was ashamed of my depression and my suicide attempt. It was something I could not talk about ... I felt liberated after reading Out of the Depths; I realized that I didn't have to be ashamed ... and I could do the work of evaluating how my own faith life contributed to my experience of depression and suicide attempts. I think for a while I was really trying to compartmentalize both of those experiences, like my faith didn't have anything to do with suicide... [Boisen] found affirmation from friends and family and colleagues that encouraged him to not hide that stuff but to share it in restorative ways.

In pondering how his faith and suicidal behavior fit together, Jeremy discovered that early in his life, he had adopted the notion that Christians, especially Christian clergy, were supposed to be perfect. This "anything less than perfection is sinful and wrong" theology, in conjunction with the stigma of depression and suicide that was operating in Jeremy's church, was deleterious for him. Now, as an adult steeped in an environment of theological reflexivity, moved by the writings of Boisen and liberation theologians and spurred by Emma's support, he felt empowered to relinquish those harmful views. He replaced them with the conviction "good theology begins where the pain is": "We have to look at the brokenness of the world and affirm it, say 'Yeah! This is the way that it is!' in a way that we're real about it so that we can go about the work of fixing it." Because this is how Jesus approaches his ministry, Jeremy reasoned-" not as a rich king but as a poor servant who eats with sinners and experiences homelessness and knows suffering"- then it should be how he approaches his own. "Now I understand that my authenticity in ministry is actually what makes my ministry very powerful," he said.

Christian clergy, then, should not hide their "brokenness" but use it as a starting pointa "gift," even-for their pastoral work. When Jeremy was called to pursue ordination in the UCC tradition, the committee agreed with this viewpoint. He explained,

I thought suicide was going to prevent me from being ordained, but it's actually one of the most important reasons for why the ecclesiastical body said yes-not that they're putting a toxic minister into ministry but that they're putting in a minister who understands brokenness and has done the hard work of healing. I had gone on that journey and wanted to minister to others in the way that I understood my own healing ministry.

There are two lovely postscripts to this story. One is that after graduating from seminary and serving as a hospital chaplain, Jeremy returned to the UCC church of his youth. This time, his experience with the church members and leadership was quite different, as "it was like being welcomed with their arms wrapped around me, just this sense of affirmation." He was able to sit down with the people who had been his colleagues and supervisors at the time of his suicide attempt and discuss that period with them. He learned that they had had far more tenderness and concern for him than he perceived, or was able to perceive, at the time. "I could hear how much they struggled and how much they loved me, but they hurt, themselves, and they wrestled with what had happened to me," he said. The painful memories of being brushed off by these people important to him had become wounds, and these conversations served to heal them.

The second postscript brings us to present day, August 2021. Emma and Jeremy married and had children, whom they adore, and Emma continues to embody Godly affirmation for him. Jeremy has served as pastor at several UCC churches and, at each of them, has been an ambassador for mental health. He was instrumental in helping one adopt a designation called WISE, "Welcoming, Inclusive, Supportive, and Engaged in the Mental Health of the community and the wider world" (UCC Mental Health Network 2021), which prepares a church to be a haven for people with psychological disorders. Thus, he has gone from being ashamed and secretive about his mental illness and suicidality to being self-loving and open about it. He hopes his legacy will be to encourage other 
people to do the same, especially if they feel silenced, shamed, or marginalized. "One of the healing parts in me," he said, "is thinking about small ways that I can contribute to shining light on the injustices in the world around us ... Maybe I can be prophetic in that way ... [By] contributing in some small way, I'm engaging that and I'm not just ignoring it or disregarding that other people hurt!"

\subsection{Summary of the Results}

Once it was arranged thematically and synthesized, the considerable amount of data collected from Jeremy and the other seven study participants conveyed the following:

- Religion and its attendant creeds and observances, including regular attendance at worship services, featured large in the childhood and adolescence of seven out of eight of the participants.

- All participants have religiosity or spirituality of various ilks and intensities in their lives today.

- Participants' current relationships with God range from detachment to intimacy.

- Every person has experienced religious/spiritual struggles.

- While despair was present in all participants prior to their suicide attempts, other psychoemotional and spiritual states were also operative: being "done" (five participants), perceived failure or inadequacy (five participants), and cognitive distortion (all eight).

- All attribute surviving their suicide attempts to one or more causes, from the mundane/practical to the supernatural/divine, and most recognize a grander purpose for their existence.

- Healthy coping methods and spiritual factors keep each of them from acting on continuing suicidal ideation.

- All currently engage in advocacy, helping, caregiving, or ministry in a professional or volunteer capacity.

- All have confronted their personal history of suicide attempts and pondered the changes in their relationships with life and death since surviving the attempts. Several speak and write publicly about their experiences with suicide. All harbor compassion for people who experience suicidality.

- Every person's story includes turning points, some with patently spiritual elements, that have resulted in a desire to live.

\section{Discussion}

In qualitative research, the discussion section presents a "secondary level of analysis" of the data, tying in prior theory and research to generate "interpretative insights" (Bloomberg and Volpe 2012, p. 187). To accomplish that in this project, I will lean on the categories proposed by Whalley (1964) for the various ways that religion and suicide may interact with one another. The objective of this hermeneutic endeavor is to provide a layered view of the phenomenon being examined-the intersections of religion/spirituality and suicidality in the lives of suicide attempt survivors-with the intention of demonstrating its complexity in a way that little research has done up to now.

\subsection{Whalley's Model}

American psychologist Elsa Whalley was an esteemed suicidologist in the early days of the field and a fellow at Shneidman's Los Angeles Suicide Prevention Center from 1962 to 1963 . In 1964, she wrote a journal article ${ }^{5}$ ahead of its time containing musings on religion as it pertains to suicide. She poses two questions that are arguably the crux of psychology-focused suicidology: "Why are some people able to tolerate excruciating circumstances-and sometimes even turn them to creative use-while others break under what seems to be the same amount of pressure? Why is it that at times when suicide would seem almost to be a rational solution [such as in concentration camps], people do not use it" (Whalley 1964, p. 94)? 
Pointing out that Durkheim's theory does not shed light on the matter, as it describes suicide at the societal level rather than the individual, she contends that the extent to which people believe that the "'escape hatch" from life is always open" is what ultimately guides them to choose suicide (Whalley 1964, p. 98). The rub, though, is that this belief goes against the teachings of Christianity and Judaism, religions prevalent in the US. Either none of the people who kill themselves had been religiously involved while alive, which, Whalley says, is not statistically likely in a country as religious as the US, or their religiosity did not deter them from suicide. Thus, it behooves interested parties to examine the role of religion in suicide and determine when it might not serve a protective function.

Whalley remarks, "In suicide and in religion alike, we are dealing with phenomena which exist-and therefore must be viewed-at the same time on the macroscopic (sociological) and microscopic (psychological) levels. We need an approach which allows easy shift of focus to either level ... [that is,] a multi-dimensional concept of religiosity or religious behavior" (Whalley 1964, p. 102). She proffers just such an approach, a model of religion as it relates to "suicidal behaviors ... [and] the belief that suicide is a good solution to life's problems" (Whalley 1964, p. 95), which I collectively call "suicidality" in this paper. Whalley bases her model on the epidemiological model of disease-not that suicide should be taken literally as a disease, she counsels. More particularly, she likens the modes by which religion can influence suicidality to the "constellation of factors or circumstances in a special set of interrelationships which are involved in producing a disease process" (Whalley 1964, p. 94). In Whalley's model, religion may be:

- The source of the notion that suicide is an option. This is the case, Whalley explains, when religion promotes suicide or renders it attractive, such as by promising reunion with loved ones in an afterlife or the opportunity to "merge into the universe" (Whalley 1964, p. 105) after death. It is also at play when one believes one is being commanded by religion to take one's life or when one "identif[ies] with Christ and must therefore kill [one]self" (Whalley 1964, p. 105).

- Suicido-genic ${ }^{6}$. Religion may "nourish a suicidal idea" that originated elsewhere: hearing an account of someone's suicide and finding oneself to be like-minded, for instance, or "studying the works of Nietzsche" (Whalley 1964, p. 105). In addition,

if a person has been socialized in a religion that stressed Man's worthlessness and sinfulness and portrayed human beings more as worms than angels, in a time of crisis or depression the individual may feel complete despair. The suicidal hypothesis may then take root or may come to consciousness if it has been dormant. If his religion has made shame, guilt, fear, and punishment more vivid and real to him than love, hope, joy, and forgiveness, religious counselors will find it difficult to convince him of the reality of the hopeful side of his religion-even if he wants to believe. (Whalley 1964, p. 105)

Whalley points out that Judeo-Christian faiths teach contradictory beliefs simultaneously, such as depicting God as both loving and chastising, and some religions advance decidedly negative views of human nature and conduct. This championing of unsympathetic doctrines runs the risk of inducing "guilt and self-hatred" in their affiliates, which "often make an excellent subsoil in which suicidal impulses may flower and bear fruit" (Whalley 1964, p. 105).

- $\quad$ Suicido-static. By contrast, religion can inhibit the maturation of suicidality, such as when religious conversion or deepened religious conviction mitigates depression or guilt by providing hope or forgiveness, or when one joins a supportive religious community that channels one's suicidality into more constructive thoughts and actions.

- $\quad$ Suicido-cidal. Religion can extinguish suicidal urges altogether, suddenly or gradually. Whalley describes three cases from her clinical practice in which this "killing off" of suicidality occurred abruptly after the individuals' suicide attempts. Surviving the attempt functioned as an epiphany for each of them; all three confidently attributed their survival to direct intervention by God and responded by significantly altering 
their conduct, worldview, and values. Besides losing their suicidal inclinations, they became "more interested in religion" (Whalley 1964, p. 106).

- Immunizing. "By providing a specific set of counter-beliefs supported by a social situation and rituals" (Whalley 1964, p. 106), religion can create conditions hostile to either the germination or the acting-upon of suicidal thoughts. In such cases, says Whalley, suicide "becomes literally unthinkable" or at least not "within the realm of [one's] own action-possibilities" (Whalley 1964, p. 106). As examples she discusses the life-oriented philosophies of Judaism and Catholicism and the latter's characterization of suicide as "one of the few sins for which there is no escape from eternal punishment" (Whalley 1964, p. 106).

All these possibilities depend, of course, on the would-be suicidal person's receptivity to religion. For some suicidal people, religion is inconsequential. Perhaps they were not sufficiently exposed to religion for it to have an appreciable effect on their suicidality, perhaps they rejected it before they became suicidal, or, more likely (in a setting like the US where most people are religiously or spiritually involved), whatever form of religion/spirituality is operating in their lives simply cannot prevail over their suicidal gloom. It might be deficient or ill-suited to them, or maybe they cannot cognitively access it in their overwhelmed state. Whalley writes, "A number of suicidal patients told us that when they were considering suicide, thoughts about religion (either as a help or a deterrent) 'simply never entered my mind.' All they seem to have thought about was their central pressing problem and how to solve it, to 'get away from it all,' 'to get some sleep,' 'some peace' and so on" (Whalley 1964, p. 109). This instance of religion's having a negligible bearing on a person's suicidality she straightforwardly names "no role."

Whalley's model is both highly applicable to my findings and conceptually kindred to my project. It allows for a variety of relationships between religion and suicide; consequently, religion can occupy more roles than just the buffer against suicidality that it has been pigeonholed into by most of the literature. The model is also versatile and egalitarian. It does not prioritize or hierarchize its component propositions, nor are they dependent on one another. When applied to a case, any of its propositions - or more than one at oncecould hold true, and if one were found not to, the whole model would not be nullified. For these reasons, I will avail myself of this useful model in discussing my findings—with one amendment: I will expand Whalley's term "religion" to incorporate spirituality. Doing so will broaden the possible occasions in which suicidality may be affected by the holy. Had Whalley developed her model today, I am confident it would have included spirituality.

\subsection{Results Set within Whalley's Model and Related to the Literature \\ 4.2.1. Religion/Spirituality as Suicidogenic}

Religion/spirituality is suicidogenic if it plants the seed that suicide is a reasonable or attractive option. Whalley writes that religion rarely plays "extreme roles" such as directly inciting or hindering suicide; "most of the time it is difficult to tease out its function in the suicidal situation" (Whalley 1964, p. 104). For this reason, as well as the terminology issues I explained in my earlier footnote, I will refrain from discussing religion/spirituality as the source per se of suicidality and instead refer to it as a contributor to it.

In the eight study participants' lives, suicidogenesis occurred passively, when religion/spirituality failed to hinder them from attempting suicide, and actively, when it instigated their suicidality. Passive suicidogenesis was rampant. None of the buffering mechanisms typically proposed in the suicidological literature worked for them (although not every participant was exposed to every one): the prohibitions against suicide and threats about the horrible fate that befalls those who take their own lives; the furnishing of a network of supportive coreligionists; the enabling of closeness and reciprocity with a transcendent entity; the promotion of wholesome activities, behaviors, and attitudes that reduce the incidence of suicide risk factors such as substance abuse and depression; the fostering of an optimistic worldview and a sense of meaning and purpose; or the provision of a framework for interpreting and coping with adversity, suffering, and stress. 
Three quarters of the participants also experienced active suicidogenesis. These six reported that at various times before their suicide attempts, and in various combinations, they perceived a dismissive or scornful religious community, conflict with or doubt about God, crises of meaning and purpose, shame-provoking doctrines about the sinfulness and flawed nature of humans, insinuations of "you'll never be good enough," tenets and values that clashed with their own, inflexible dogma, simplistic or inapplicable religious instruction, subliminal advancement of the notion of the redemptive power of self-sacrifice (including death), indecorous conduct from the supposedly pious people around them, stigmatization and inadequate discussion of suicide and mental illness, and insufficient pastoral care. Readers will recognize most of these themes in Jeremy's story. They are consistent with the growing research showing that religion/spirituality does not always protect against suicidality.

\subsubsection{Religion/Spirituality as Suicido-Static}

"In its suicido-static function," writes Whalley, "religion inhibits the development of the disease but does not kill the 'virus,' the suicidal hypothesis [that ending one's life is a feasible choice]" (Whalley 1964, p. 105). In the lives of the eight people in this study, suicido-stasis is taking place currently and recurrently: religion/spirituality prevents or deescalates suicidality every time it imbues their coping and self-soothing, informs their reasons for living, and fosters joie de vivre. Each person named multiple examples of this. Jeremy was in the minority in that the practices that connect him with "God or a sense of goodness," which is how I phrased the interview prompt, are equally religious and spiritual; this is not surprising, since he is an ordained minister who derives fulfillment from his clerical, pastoral, and theological work. For most of the other participants, though, religion is absent from their lives today, while spirituality abounds.

The most common spiritual practices cited were meditating, attending spiritual retreats, playing/listening to music, reading, spreading kindness, and doing advocacy work. These activities were noted to facilitate one or more of the following: wonder, contentment, beauty, belonging, affirmation, empathy, gratitude, self-worth, serenity, and connection to the world, and each was found to temper suicidality. This accords with one study's finding that the religious/spiritual traditions that "emphasize self-compassion, charity, and personal redemption" seem to reduce suicide risk (Bryan et al. 2015, p. 76). Each participant, in his or her own special way, has evidently managed to achieve a level of harmony within his or her spiritual self that, were it even attained prior to his or her suicide attempt(s), was not sustained. Pargament and colleagues call such harmony "wholeness in an individual's orienting system, which is comprised of values, beliefs, practices, emotions, and relationships that offer direction and stability in the search for significance" (Pargament et al. 2016, p. 379; see Pargament et al. 2014 for the related concept of a well-integrated spiritual orienting system).

Religion and spirituality also surfaced in most participants' attributions for their survival. These individuals derive felicitous meaning from not dying, such as the sense that their purpose on earth has not yet been fulfilled. Those who mentioned having a relationship with God post-suicide attempt described God as a force of benevolence rather than punishment, rage, or revenge. Although I did not administer the religious/spiritual coping assessment RCOPE to the interviewees, their reported religious/spiritual practices and beliefs suggest positive coping in all five RCOPE domains: finding meaning, gaining mastery and control, gaining comfort and closeness to God, gaining intimacy with others, and achieving a life transformation (Pargament 1997; Pargament et al. 2013c). Taken together, they comprise real-life examples of "life-giving theologies of traumatic suffering" (Doehring 2015, p. 134) and are a considerable arsenal against the maturation of continued suicidality. 


\subsubsection{Religion/Spirituality as Suicido-Cidal}

Religious "suicido-cide" is what transpires when religion "kills off" one's wish to kill oneself (Whalley 1964, p. 106). Of the eight study participants, only Jeremy experienced this; thoughts of suicide persisted for years in the other participants after their initial suicide attempt and, for many of them, are still present today. Half made additional suicide attempts. Jeremy, then, is a fortunate exception. The eradication of his suicidal urges was not instant, however, and is only indirectly related to religion. Recall that two weeks after his suicide attempt, he had what he called a "minor attempt" that consisted of swallowing a bunch of pills. Even though he did not have strong intent to die and doubted the dose would be lethal, the act is still on the suicide continuum; therefore, suicidality was still present. His amenability to suicide as an option would start to change the following morning, but "moments of deep sadness, depression, and struggle" would linger. It would take meeting Emma and cultivating a relationship (later, a marriage) with her for the totality of his suicidality, including ideation, to vanish. He explained, "One reason that I believe I never felt suicidal again was that [Emma] never let me feel ashamed of feeling depressed. She has always asked me to be honest with her and we would figure it out together. Her total affirmation of me, depression and all, has been my safety net." It seems, then, that the extermination of Jeremy's suicidality is more attributable to an interpersonal cause than a religious one. Religion/spirituality is implicated only to the extent that Jeremy regards affirmation from his wife as religious/spiritual.

I propose, based on data from this study, that suicido-cide can assume a second form, one that Whalley does not specify. Religion/spirituality can "kill" suicide-not just the inclination toward it but the lethal act itself-by helping to block the fatal outcome of a suicide attempt. My reasoning is this: when a person survives a suicide attempt, in a sense, death "dies" and life "lives." If religion is the agent by which the person's death died-that is, the killer-then religious suicido-cide has occurred. I admit that this is an oblique, even poetic perspective, yet I argue that it has a rightful place in Whalley's model.

Such suicido-cide transpired for five of this study's participants, the ones who attribute their survival to a spiritual or supernatural cause. In Jeremy's case, his last-minute effort to save himself by finding his phone and calling his therapist was compelled by the desperate wish of his "shadow" to be brought into the light. While he did not explicitly label his shadow "spiritual," the way he described it suggests numinous qualities, something more metaphysical than a basic biological drive. Arguably, for Jeremy and four others, an uncanny, perhaps even divine force impeded their suicide attempt and therefore "killed" their intended death.

\subsubsection{Religion/Spirituality as Immunizing}

It goes without saying that because the participants in this study attempted suicide, no protective factors in their life, religious or otherwise, "immunized" them against doing so. Of note, though, is that religion was as ineffective a vaccine for the seven participants who had had lots of exposure to it while growing up as it was for the one who had had very little. I am reminded of an observation by Hillman: "Suicide serves notice on theology by showing that one does not dread its ancient weapons: the hereafter and the last judgment" (Hillman [1965] 2011, p. 32).

\subsubsection{Religion/Spirituality as Inconsequential}

Because religion and especially spirituality are still playing manifold roles in the lives of the eight participants since their suicide attempts, Whalley's proposition that religion could play "no role" in suicidality does not apply to the post-attempt period for any of them. As for prior to the suicide attempts, only two participants deemed religion immaterial to the formation of their suicidality; one participant had not had enough exposure to religion for it to make a difference, and the other never formed a solid enough attachment to the church of her youth for it to sway her immense suicidal depression. What is left is the period surrounding the suicide attempts, starting at the point that the individuals 
"committed to" the act of suicide (as Jeremy termed it) and ending with the would-be lethal act. For all eight, this was also when their desire to die was strongest, according to their responses on the Background Information Sheet. It is not a clearly delineated period; at least, my study did not endeavor to delineate it, and I suspect other researchers would find it challenging to do so because of how subjective it is. During this vague period, religion was inconsequential for all eight.

Jeremy's psychoemotional experiences during his suicide attempt mirror the other participants'. Recall the snowball effect that despair had on him, eventually infiltrating his psyche to the degree that he saw suffering everywhere he turned. When it came to the important relationships in his life (family members, girlfriend, friends, colleagues, therapist, church members), he felt invisible or dismissed. The world became a harsh, cheerless place. The crucial aspect of his anhedonia was how permanent it felt; Jeremy was certain that things would never improve. The pain seemed insurmountable, and suicide presented itself as the only analgesic. This "constriction of the mind," or "tunnel vision" (Shneidman 1993, 1996), is a hallmark of suicidal cognition. People with such constriction have crossed the threshold from disconsolateness to suicidal despondency and feel less and less able to abide it. Coping methods_- "the range of options usually available to that individual's consciousness when the mind is not panicked"-become inaccessible, even if they were relied on in the past, and ultimately "cessation" is arrived at as the most viable solution, since staying miserable is not tenable (Shneidman 1993, p. 40).

Another common feature of the suicidal mindset is "cognitive deconstruction," regression to a kind of low-level thinking in which notional thought largely disappears, as do the capacities for meaning-making and looking to the future. Consequently, suicidal people can only attend to concrete, simple, and immediate sensations and goals (Baumeister 1990; Joiner 2010). I suspect this is because their brain is streamlining its mentation, ignoring whatever it deems superfluous as it gears up for the extraordinarily difficult trifold task of dying, killing, and being killed (as described by Mellor 1979, among others). As their perspective narrows, everything not involved in the mechanics of ending their life becomes relegated to the unseen periphery, including hope and reasons for living. Accordingly, religion would be one of the casualties; not only is it extraneous to the execution of suicide, it also requires advanced cognition to comprehend, much less apply. As one of this study's participants pointed out, religious concepts such as hell are "abstract," practically ungraspable by a brain hyper-focused on suicide. Religion/spirituality would, thus, lose its effectiveness as a deterrent-if, of course, it had had it in the first place.

One might even think of suicidal individuals' cognitive constriction as a Weltanschauung, drastic and all-encompassing, in which they can scarcely imagine ever having not wished to perish or are so pained by the memory of a time when they did not want to die-a bitter reminder of what will never again be-that they spurn it. One participant captured this experience well: when he is most suicidal, he said, he cannot fathom ever having not been suicidal, but when he is content and "grounded," as at the time of the interview, he can neither access nor fully appreciate his suicidal state of mind.

Preeminent suicidologist Thomas Joiner describes this cognitive shift as a "break in natural, usual thought about death. The break is to leave behind evolution's handiwork that we fear and revile death, and instead come to embrace it as nurturing, comforting, even loving" (Joiner 2010, p. 110). Suicidal people have achieved this break and stepped into an existential arena where life and death hold entirely different meanings than they do for the non-suicidal. "The logic of suicide is different," writes Alfred Alvarez in The Savage God (Alvarez [1971] 1992, p. 61), discussing his friend Sylvia Plath's suicide. In a phenomenon he calls "the closed world of self-destruction" (Alvarez [1971] 1992, p. 62), suicide becomes a "vocation" (Alvarez [1971] 1992, p. 63). In fact, in the poem "Lady Lazarus" Plath herself asserts, "Dying/ Is an art, like everything else./ I do it exceptionally well./ [ . . ] I guess you could say I've a call" (Plath [1960] 1992). Once suicidal individuals have entered this realm, anything they experience can function as a feedback loop that reinforces the decision to end their life. "An argument with a stranger in a bar, an expected 
letter which doesn't arrive, the wrong voice on the telephone, the wrong knock at the door, even a change in the weather-all seem charged with special meaning; they all contribute" (Alvarez [1971] 1992, p. 61).

I submit that religion and spirituality were rendered powerless in the face of Jeremy's and the other participants' distorted cognition. What transpired for them psychoemotionally during their suicide attempts provides the strongest evidence for Whalley's supposition that religion could play "no role" for a suicidal person.

\subsubsection{Summary of Results Set within Whalley's Model}

In sum, for the eight participants in this study, the point at which they summoned religion/spirituality relative to their suicide attempts, combined with key characteristics (how harmoniously integrated religion/spirituality was into their life, how benevolent its tenets, how life-giving its practices, how accepted they felt by coreligionists and God, etc.), appeared to significantly affect whether it was suicide-promoting, suicide-inhibiting, or inconsequential for them. When they were in the throes of severe suicidality, at the time of their suicide attempts, they were not able to access religion or spirituality. Table 2 provides a summary of these results.

Table 2. Summary of the findings set within Whalley's model.

\begin{tabular}{|c|c|c|}
\hline $\begin{array}{l}\text { Role of Religion/ } \\
\text { Suicide (RS) }\end{array}$ & Definition & $\begin{array}{l}\text { Evidence for It in This Study and \# of } \\
\text { Participants Who Experienced It }\end{array}$ \\
\hline Suicidogenic & Exacerbating suicidality & $\begin{array}{l}\text { Prior to the suicide attempts, RS failed to } \\
\text { stymie suicidality ( } 8 \text { participants) and } \\
\text { actively contributed to suicidality (6) }\end{array}$ \\
\hline Suicido-static & Attenuating suicidality & $\begin{array}{l}\text { Since the suicide attempts, RS has been } \\
\text { informing coping and reasons for living (8) }\end{array}$ \\
\hline Suicido-cidal & $\begin{array}{l}\text { Exterminating suicide or } \\
\text { suicidality }\end{array}$ & $\begin{array}{l}\text { RS possibly aided in the elimination of } \\
\text { suicidality (1) and helped to thwart death (5) }\end{array}$ \\
\hline Immunizing & $\begin{array}{l}\text { Rendering suicide } \\
\text { undoable }\end{array}$ & Not applicable \\
\hline $\begin{array}{l}\text { Inconsequential/ } \\
\text { no role }\end{array}$ & $\begin{array}{l}\text { Having no effect on } \\
\text { suicidality }\end{array}$ & $\begin{array}{l}\text { Prior to the suicide attempts, RS was absent } \\
\text { or too weak (2); during the attempts, the } \\
\text { protective effects of RS disappeared (6) }\end{array}$ \\
\hline
\end{tabular}

\section{Limitations}

The qualitative design of this study is both a strength and a limitation. While it allowed for a comprehensive examination and textured account of religion and spirituality as they have interfaced with the suicidality of eight suicide attempt survivors, the findings only pertain, of course, to those eight. Alas, what the qualitative method gains in depth, detail, and intimate understanding, it loses in breadth and generalizability. My being the sole researcher and author is also a limitation; collaborating with colleagues on this project could have bolstered its trustworthiness and credibility and reduced the risk of its being affected by bias. In virtually all research, the researcher's "positionality" and "social, cultural, political, psychological, [and] institutional" identities might—perhaps will-influence any part of the research process (Bloomberg and Volpe 2012, p. 174). This study, of course, is no exception. I strove to minimize these effects through meticulous, iterative checking of my codes and faithful relaying of Jeremy's and the other participants' stories using a wealth of quotations.

\section{Future Directions}

\subsection{Recommendations for Researchers}

Other researchers are encouraged to build on the results of this study. The following questions are promising leads for future investigations: 
1. Is religion/spirituality ever accessed after individuals have made up their mind to end their life, their cognition is constricted, and a suicide attempt is imminent? If so, what forms does it take? Does a certain type of religion/spirituality or religious/spiritual practice have the most potential to decrease suicidality at that time?

2. At what point does beneficial religion/spirituality stop working (become inconsequential) prior to an attempt?

3. How can religion/spirituality's "life-giving" effects be strengthened during a suicidal crisis?

4. What is the typical relationship between atheism and suicide, and what factors are most operative within this relationship?

5. What types of religion-based suicide stigma are most harmful to people with suicidal ideation?

6. Which religious/spiritual struggles correlate most strongly with suicidality?

7. Which forms of religious/spiritual coping work best for people with suicidal ideation and its accompanying cognitive and affective states (hopelessness, despair, burdensomeness, alienation, etc.) or for those healing from the trauma of a suicide attempt?

I lift up the qualitative paradigm as the most suitable for conducting these inquiries. I ask researchers who nevertheless stay with quantitative modes to be mindful of the multidimensional, subjective nature of religion, religiosity, spirituality, and suicidality and do their best to avoid flattening these dimensions and peculiarities. They should also bear in mind that religion and spirituality do not necessarily overlap for all people (especially with a research sample that is apt to be "spiritual but not religious"), so measurement techniques should keep these concepts separate. Colucci (2008) discusses many of the scales that assess the more subtle, ethereal facets of spirituality. These and other spirituality-sensitive instruments, such as the RCOPE and the Religious and Spiritual Struggles Scale, should be chosen over less sensitive ones. Constructs of religion and spirituality should regularly be scrutinized and improved upon based on new thinking and information; for instance, Colucci recommends the development of measures that "reflect greater sensitivity towards ethnocultural issues" (Colucci 2008, p. 89). She offers additional well-reasoned suggestions for future research with which I ardently agree, such as asking study participants how they are religious rather than whether they are religious and addressing the "personal and cultural ways of experiencing and expressing spirituality" (Colucci 2008, p. 88).

\subsection{Recommendations for Clinicians and Other Caregivers}

The literature indicates that mental health professionals are often hesitant to discuss religion/spirituality with their clients, despite clients' wish to include these considerations in their treatment (Chen and VanderWeele 2020; Exline et al. 2014; Koenig 2017; Vieten et al. 2016). One of the reasons proposed for this regrettable reluctance is clinicians' assumption that they are not qualified to discuss these matters; doing so is the exclusive purview of clergy and other religious/spiritual representatives (see Bhugra and Osbourne 2004; Colucci 2008; Mandhouj and Huguelet 2016; and Vieten et al. 2016 for more reasons). While it is, of course, ethically correct for mental health professionals not to practice outside their scope, some writers (e.g., Brownell 2015) have argued that it would be unethical for counselors to neglect an aspect of their clients' lives that is of utmost importance to them and could affect the outcome of their treatment. I suspect that some clinicians hide behind lack of training to avoid talking about religion and spirituality when the real reason is that they are uncomfortable with them. Another possibility is that because they are not used to asking clients about these subjects, they simply do not think to do so. Regardless, clinicians owe it to their clients, suicidal or not, to practice "loyalty to the soul" (Hillman [1965] 2011, p. 93) by exploring their religiosity and spirituality. Pargament (2007), among others, writes about the disservice mental health workers do to careseekers when they fail to discuss these phenomena. Though he does not mention suicide as a possible outcome of this oversight, I argue - backed by my study participants' narratives—that a suicidal client's religiosity/spirituality is a topic that a clinician cannot risk ignoring. 
To my fellow mental health caregivers, I declare: you do not have to be clergy to talk about religion and spirituality. "Addressing the spiritual needs of those at increased risk of suicide ... is not the domain of any one profession. Rather, it remains the domain of all clinical professionals who, within their respective disciplines, have something to offer their patients/clients" (Kopacz 2015, p. 81). I contend that whether or not we count ourselves among the religiously faithful, we can effectively, even adroitly, integrate religion and spirituality into our work. For one thing, we caregivers are, I presume, adept at empathy. We do not need firsthand experience with something to gain a workable understanding of it when our client talks about it, as long as we are listening attentively and embodying positive regard. For another, in a context of client-centered counseling, what matters most is not our personal history with a phenomenon (divorce, addiction, trauma, etc.) but the client's. We can apply the same compassionate clinical curiosity to clients' religiosity/spirituality that we do to the other aspects of their identity, perspectives, and experiences. Psychologist Cassandra Vieten (e.g., Vieten et al. 2016) has written extensively on spiritual and religious competencies for counseling professionals. Her work and Spiritually Integrated Psychotherapy (Pargament 2007) provide excellent starting points for clinicians looking to incorporate clients' religious/spiritual concerns into their caregiving.

I add the caveat, however, that we clinicians can damage the therapeutic relationship or, worse, do harm to our clients if we do not treat their religiosity / spirituality with delicacy, such as if we proselytize, take a judgmental or moralistic stance, invalidate or disregard their convictions, make assumptions about their beliefs or practices, or attempt to engage in a theological debate with them (Chen and VanderWeele 2020; Gearing and Alonzo 2018). Similarly, we should not foist spiritual care onto clients who do not wish for it or insist on a treatment intervention that is not sensitive to their needs (e.g., an explicitly religious focus when they adhere to a more secular spirituality—or none). Again, caregivers are obliged to assume the same professionalism in this area as we would with any other. We must step into each careseeker's experiential world and do our best to become acquainted with it on their terms, not ours. Perhaps we could even enter into creative caregiving collaborations with clerics and others who are theologically trained, who are sometimes as hesitant to talk about psychology as many in the mental health fields are to talk about religion (Mason et al. 2011).

I offer the following questions for use in care encounters with suicidal or potentially suicidal people (see Townsend 2006 for suicide prevention, intervention, and postvention strategies tailored to Christian caregivers). Because my study revealed differences in the types of religion and spirituality observed by the participants before and after their suicide attempts, I will suggest questions for both circumstances.

Questions that could be posed to careseekers who are contemplating suicide or are at risk of suicide include:

1. If you are affiliated with a faith tradition, how close a connection do you feel to it and to the other people affiliated with it?

2. If you do not feel close to or supported by the other people in that tradition and you would like to be, how could you improve that relationship?

3. How would you change your faith tradition (the worship services, the teachings, the rituals, etc.) so that it is more welcoming and fulfilling for you?

4. Which of your beliefs and values match your faith tradition's? Which do not?

5. What other faith traditions or spiritualities appeal to you? What about them do you find compelling?

6. What do you believe happens to people when they die? What if they had killed themselves?

7. What is your family's attitude toward suicide? Friends'? Community's? Religious tradition's? How have these attitudes affected your own?

8. What religious/spiritual struggles have you experienced?

9. Do you believe people are inherently good? Do you feel you are?

10. When you feel most down, what role does religion/spirituality play for you? 
11. How might religion or spirituality help if suicidal thoughts began to dominate your daily life?

12. How does the way you view or relate to God change when you are despondent?

13. If you are thinking about suicide, what are your reasons for dying? What are your reasons for living? What do you think your death would accomplish? What harm might it do? (See Freedenthal 2013 for guidance on these questions.)

14. What do you think is your purpose on earth?

Questions that could be posed to careseekers who have a history of suicidality, especially suicide attempts, include:

1. How do you explain your surviving your suicide attempt(s)? To what, if anything, do you attribute your survival?

2. What do you think is your purpose for surviving?

3. What aspects of your religion/spirituality were not working for you before the attempt(s)?

4. How might religion or spirituality have helped when you became preoccupied with thoughts of ending your life?

5. How have you changed your religion or spirituality since the attempt(s) so that there is a better fit?

6. What is your view of God? How helpful is that view for you? If you would like to have a more collaborative relationship with God, how could you move toward that?

7. How have your ideas about God changed since your suicide attempt(s)? About death? About life?

8. What practices do you have that give you a sense of goodness, vitality, or serenity? What practices could you add? What practices do not enhance your well-being?

9. If you still think about suicide, what are your reasons for dying? For living?

10. Have you experienced any spiritual awakenings or turning points in your life story? If you could write your own turning point, what would it be?

\section{Closing Thoughts}

This project is at once somber and hopeful. Tacit in its pages is grief: for those who mourn loved ones lost to suicide, for those whose urge to die is unrelenting, and especially for those who could not in this life reconcile the troubles of their soul. Yet somehow hope does not itself succumb to death. Every step of the way, I have been fueled by hope-that the bitterest despair will eventually subside, that caregivers can make a difference to the suicidality-riddled person, and that efforts such as the present one will effect new strategies for ministering to the suicidal. May all these things prove true in time.

I can think of no better way to close this paper than with the words of one of the people who entrusted me with their story. When I asked Jeremy at the end of the first interview if there was anything he wanted to add, he paused to consider the question. Then, gently, he said, "I think a prayer would be fitting." In tender, measured tones, he offered the following prayer:

Oh God, you see us. You see me, and you see Ryan. I offer you thanksgiving for the journey that each of us has taken, for this opportunity to have our journeys collide here in this triangle[-shaped] room, with light that is shining on some darkness. In the depths of that darkness there has been healing. Certainly in my life there is still healing to be had, and in Ryan's life there is still healing to be had, and in this world there is still darkness that needs more light. May you bless this work that we have committed to here; may it bless the lives of the people that it touches. May Ryan's work here be prophetic. Inscribe in the hearts of the people that she presents it to a sense of story, and belonging, and of being heard. This I pray, to you, a still-speaking God, a still-listening God, a God who says yes despite all of it. Amen. 
Funding: This research received no external funding.

Institutional Review Board Statement: The study was conducted according to the guidelines of the Declaration of Helsinki and approved by the Institutional Review Board of the University of Denver (protocol code 756567-2) on 28 September 2015.

Informed Consent Statement: Informed consent was obtained from all subjects involved in the study.

Data Availability Statement: Data can be obtained from the author.

Conflicts of Interest: The author declares no conflict of interest.

\section{Notes}

1 "Suicidality" is the instance of being suicidal; that is, inhabiting a state that can be located on the "suicide continuum," the range of increasingly lethal "ideation" (thoughts, plans, or preoccupation) or behaviors involving intentionally ending one's life (Colucci and Martin 2008; Firestone and Seiden 1990; Sveticic and De Leo 2012).

2 In this article, "spirituality" will refer to "the actualization of the basic human capacity for transcendence" (Schneiders 2011, p. 16), or, as psychologist Kenneth Pargament famously defines it, a "search for the sacred" (Pargament 2007, p. 53). It is the subjective way a person experiences the numinous (Piedmont et al. 2020). "Religion," meanwhile, is an organized system of beliefs, practices, rituals, ceremonies, symbols, values, and sacred texts (Pargament et al. 2013a). "Religiosity," sometimes called "religiousness," is the extent to which a person participates in religion internally, such as by belief, or externally, such as by action.

3 Suicides carried out for this reason, similar to those motivated by the belief that one will be sainted or rewarded after death for killing oneself, might not involve psychache. In such cases, they would be different from the type of suicide that is the focus of this article, suicide that stems from emotional agony.

4 The use of first person is a convention in qualitative research, the mode of this project. Consistent with the postmodern spirit of the paradigm, researchers' use of "I" emphasizes their inescapable subjectivity; encourages accountability, reflexivity, and transparency; and implies the social and person-based nature of the research encounter (C. Webb 1992).

5 Whalley's name is erroneously listed as "Whalen" in the article.

6 I find Whalley's use of this term confusing. Since a genesis is an origin, "suicido-genic" more aptly describes the source of suicidality rather than something that augments or aggravates it, which is how she uses it. Perhaps a more suitable medical term for her intended meaning would be "suicido-trophic" (suicidality-nourishing) or "suiciditic" (suicidality-inflaming). Nevertheless, I will observe "suicido-genic" as she defines it, but I will conflate it with the religion-as-source concept. In other words, "suicido-genic" as I use it will describe something that acts as either the germ or the provocateur of suicidal ideation or behavior. This is consistent with other scholars' use of it (e.g., Eskin et al. 2020). I will also drop the hyphen in accordance with the modern convention.

\section{References}

Alvarez, Alfred. 1992. The savage god. In On Suicide: Great Writers on the Ultimate Question. Edited by John Miller. San Francisco: Chronicle Books, pp. 60-88. First published 1971.

American Association of Suicidology [AAS]. 2021. Suicide in the US (2019 Data). Last modified January 2021. Available online: https:/ / suicidology.org/facts-and-statistics / (accessed on 10 August 2021).

Ammerman, Nancy Tatom. 2014. Sacred Stories, Spiritual Tribes: Finding Religion in Everyday Life. New York: Oxford University Press.

Baetz, Marilyn, and Rudy Bowen. 2011. Suicidal ideation, affective lability, and religion in depressed adults. Mental Health, Religion $\mathcal{E}$ Culture 14: 633-41. [CrossRef]

Baumeister, Roy F. 1990. Suicide as escape from self. Psychological Review 97: 90-113. [CrossRef] [PubMed]

Bhugra, Dinesh, and Thomas R. Osbourne. 2004. Spirituality and psychiatry. Indian Journal of Psychiatry 46: 5-6. Available online: https: / /www.ncbi.nlm.nih.gov / pmc/articles/PMC2912677/ (accessed on 8 August 2021). [PubMed]

Bloomberg, Linda Dale, and Marie Volpe. 2012. Completing Your Qualitative Dissertation: A Road Map from Beginning to End, 2nd ed. Thousand Oaks: SAGE.

Blosnich, John R., Susan De Luca, Megan C. Lytle, and Chris Brownson. 2020. Questions of faith: Religious affiliations and suicidal ideation among sexual minority young adults. Suicide and Life-Threatening Behavior 50: 1158-66. [CrossRef] [PubMed]

Borges, Guilherme, Matthew K. Nock, Josep M. Haro Abad, Irving Hwang, Nancy A. Sampson, Jordi Alonso, Laura Helena Andrade, Matthias C. Angermeyer, Annette Beautrais, Evelyn Bromet, and et al. 2010. Twelve-month prevalence of and risk factors for suicide attempts in the World Health Organization World Mental Health Surveys. Journal of Clinical Psychiatry 71: 1617-28. [CrossRef] [PubMed]

Brownell, Philip. 2015. Spiritual Competency in Psychotherapy. New York: Springer.

Bryan, Craig J., Eugena Graham, and Erika Roberge. 2015. Living a life worth living: Spirituality and suicide risk in military personnel. Spirituality in Clinical Practice 2: 74-78. [CrossRef] 
Centers for Disease Control and Prevention [CDC]. 2021. Facts about Suicide. Last modified August 2021. Available online: https://www.cdc.gov/suicide/facts/ (accessed on 10 August 2021).

Cerel, Julie, Margaret M. Brown, Myfanwy Maple, Michael Singleton, Judy Van de Venne, Melinda Moore, and Chris Flaherty. 2019. How many people are exposed to suicide? Not six. Suicide and Life-Threatening Behavior 49: 529-34. [CrossRef]

Chen, Ying, and Tyler J. VanderWeele. 2020. Spirituality, religion, and suicide. In Handbook of Spirituality, Religion, and Mental Health, 2nd ed. Edited by David H. Rosmarin and Harold G. Koenig. London: Academic Press, pp. 27-40.

Colucci, Erminia. 2008. Recognizing spirituality in the assessment and prevention of suicidal behaviour. World Cultural Psychiatry Research Review 3: 77-95.

Colucci, Erminia. 2012. Spirituality, religion and suicide. In Suicide: A Global Perspective. Edited by Maurizio Pompili. Bussum: Bentham eBooks, pp. 73-101. [CrossRef]

Colucci, Erminia. 2013. Culture, cultural meaning(s), and suicide. In Suicide and Culture: Understanding the Context. Edited by Erminia Colucci and David Lester. Cambridge: Hogrefe, pp. 25-46.

Colucci, Erminia, and Graham Martin. 2008. Religion and spirituality along the suicidal path. Suicide and Life-Threatening Behavior 38: 229-44. [CrossRef] [PubMed]

Creswell, John W. 2013. Qualitative Inquiry and Research Design: Choosing among Five Approaches, 3rd ed. Thousand Oaks: SAGE.

Currier, Joseph M., Phillip N. Smith, and Shane Kuhlman. 2017. Assessing the unique role of religious coping in suicidal behavior among U.S. Iraq and Afghanistan veterans. Psychology of Religion and Spirituality 9: 118-23. [CrossRef]

Currier, Joseph M., Ryon C. McDermott, Wesley H. McCormick, Marc C. Churchwell, and Lori Milkeris. 2018. Exploring cross-lagged associations between spiritual struggles and risk for suicidal behavior in a community sample of military veterans. Journal of Affective Disorders 230: 93-100. [CrossRef] [PubMed]

Dein, Simon. 2005. Spirituality, psychiatry and participation: A cultural analysis. Transcultural Psychiatry 42: 526-44. [CrossRef]

Doehring, Carrie. 2015. The Practice of Pastoral Care: A Postmodern Approach (Revised and Expanded Edition). Louisville: Westminster John Knox Press.

Dua, Devakshi, Susanta Padhy, and Sandeep Grover. 2021. Comparison of religiosity and spirituality in patients of depression with and without suicidal attempts. Indian Journal of Psychiatry 63: 258-69. [CrossRef] [PubMed]

Durkheim, Émile. 1951. Suicide: A Study in Sociology. Translated by John A. Spaulding, and George Simpson. New York: Free Press. First published 1897.

Eskin, Mehmet, Ulrich S. Tran, Mauro Giovanni Carta, Senel Poyrazli, Chris Flood, Anwar Mechri, Amira Shaheen, Mohsen Janghorbani, Yousef Khader, Kouichi Yoshimasu, and et al. 2020. Is individualism suicidogenic? Findings from a multinational study of young adults from 12 countries. Frontiers in Psychiatry 11: 259. [CrossRef]

Exline, Julie J., Kenneth I. Pargament, Joshua B. Grubbs, and Ann Marie Yali. 2014. The Religious and Spiritual Struggles Scale: Development and initial validation. Psychology of Religion and Spirituality 6: 208-22. [CrossRef]

Fahmy, Dalia. 2018. Americans Are Far More Religious than Adults in Other Wealthy Nations. Retrieved from Pew Research Center Website. Available online: https:/ / www.pewresearch.org/fact-tank/2018/07/31/americans-are-far-more-religious-than-adultsin-other-wealthy-nations / (accessed on 10 August 2021).

Firestone, Robert W., and Richard H. Seiden. 1990. Suicide and the continuum of self-destructive behavior. Journal of American College Health 38: 207-13. [CrossRef] [PubMed]

Freedenthal, Stacey. 2013. What Are Your Reasons for Living? Speaking of Suicide (blog). Available online: http://www. speakingofsuicide.com/2013/06/03/reason/ (accessed on 17 August 2021).

Gearing, Robin Edward, and Dana Alonzo. 2018. Religion and suicide: New findings. Journal of Religion and Health 57: 2478-99. [CrossRef]

Geertz, Clifford. 1973. The Interpretation of Cultures: Selected Essays. New York: Basic Books.

Gibbs, Jeremy J., and Jeremy Goldbach. 2015. Religious conflict, sexual identity, and suicidal behaviors among LGBT young adults. Archives of Suicide Research 19: 472-88. [CrossRef] [PubMed]

Goodwin, Natalie P. 2013. Suicide and Eating Disorders: The Role of Religiosity, Spirituality and Religious Coping Style. Ph.D. dissertation, University of Alabama at Birmingham, Birmingham, AL, USA. ProQuest number 3591619.

Hall, Elizabeth Ryan. 2017. "Maybe Jesus Was Suicidal Too": A Qualitative Inquiry into Religion and Spirituality in Suicide Attempts. Ph.D. dissertation, University of Denver and Iliff School of Theology Joint Doctoral Program, Denver, CO, USA. ProQuest number 10286483.

Hillman, James. 2011. Suicide and the Soul. Putnam: Spring. First published 1965.

Hjelmeland, Heidi. 2013. Suicide research and prevention: The importance of culture in "biological times". In Suicide and Culture: Understanding the Context. Edited by Erminia Colucci and David Lester. Cambridge: Hogrefe, pp. 3-23.

Hjelmeland, Heidi, and Birthe Loa Knizek. 2010. Why we need qualitative research in suicidology. Suicide and Life-Threatening Behavior 40: 74-80. [CrossRef]

Hjelmeland, Heidi, and Birthe Loa Knizek. 2011. What kind of research do we need in suicidology today? In International Handbook of Suicide Prevention: Research, Policy and Practice. Edited by Rory C. O'Connor, Stephen Platt and Jacki Gordon. Chichester: Wiley-Blackwell, pp. 591-608.

Hjelmeland, Heidi, and Birthe Loa Knizek. 2016. Time to change direction in suicide research. In The International Handbook of Suicide Prevention, 2nd ed. Edited by Rory C. O'Connor and Jane Pirkis. Chichester: Wiley-Blackwell, pp. 696-709. 
Joiner, Thomas E. 2010. Myths about Suicide. Cambridge: Harvard University Press.

Jongkind, Matthias, Bart van den Brink, Hanneke Schaap-Jonker, Nathan van der Velde, and Arjan W. Braam. 2019. Dimensions of religion associated with suicide attempt and suicide ideation in depressed, religiously affiliated patients. Suicide and LifeThreatening Behavior 49: 505-19. [CrossRef]

Knizek, Birthe Loa, Johnny Andoh-Arthur, Joseph Osafo, James Mugisha, Eugene Kinyanda, Charity Akotia, and Heidi Hjelmeland. 2021. Religion as meaning-making resource in understanding suicidal behavior in Ghana and Uganda. Frontiers in Psychology 12: 549404. [CrossRef]

Koenig, Harold G. 2017. To believe or not to believe: The role of faith in treating mental illness and preventing suicide. Christian Counseling Today 21: 28-32.

Koenig, Harold G., Dana E. King, and Verna Benner Carson. 2012. Handbook of Religion and Health, 2nd ed. New York: Oxford University Press.

Kopacz, Marek S. 2015. Spirituality and suicide prevention: Charting a course for research and clinical practice. Spirituality in Clinical Practice 2: 79-81. [CrossRef]

Kopacz, Marek S., Eric Silver, and Robert M. Bossarte. 2014. A position article for applying spirituality to suicide prevention. Journal of Spirituality in Mental Health 16: 133-46. [CrossRef]

Kral, Michael J., Paul S. Links, and Yvonne Bergmans. 2012. Suicide studies and the need for mixed methods research. Journal of Mixed Methods Research 6: 236-49. [CrossRef]

Lawrence, Ryan E., Maria A. Oquendo, and Barbara Stanley. 2016. Religion and suicide risk: A systematic review. Archives of Suicide Research 20: 1-21. [CrossRef]

Lester, David. 2000. Why People Kill Themselves: A 2000 Summary of Research on Suicide. Springfield: Charles C. Thomas.

Lytle, Megan C., John R. Blosnich, Susan M. De Luca, and Chris Brownson. 2018. Association of religiosity with sexual minority suicide ideation and attempt. American Journal of Preventive Medicine 54: 644-51. [CrossRef]

Mandhouj, Olfa, and Philippe Huguelet. 2016. Why it is important to talk about religion. In Understanding Suicide: From Diagnosis to Personalized Treatment. Edited by Philippe Courtet. Cham: Springer International, pp. 257-65.

Maris, Ronald. W., Alan L. Berman, and Morton M. Silverman. 2000. Comprehensive Textbook of Suicidology. New York: Guilford Press.

Mason, Karen E., Pablo Polischuk, Raymond Pendleton, Elizabeth Bousa, Rebekah Good, and James D. Wines Jr. 2011. Clergy referral of suicidal individuals: A qualitative study. Journal of Pastoral Care E Counseling 65: 1-11. [CrossRef]

McGraw, James S. 2020. Religious/Spiritual Struggles, One-Upmanship, Internalized Homophobia and Suicide Risk among Lesbian, Gay, Bisexual, Queer/Questioning and Same-Sex Attracted Latter-Day Saints. Ph.D. dissertation, Bowling Green State University, Bowling Green, OH, USA. ProQuest number 28377495.

McGuire, Meredith B. 2008. Lived Religion: Faith and Practice in Everyday Life. New York: Oxford University Press.

Mellor, Ken. 1979. Suicide: Being killed, killing, and dying. Transactional Analysis Bulletin 9: 182-88. [CrossRef]

Nelson, Graham, Ryan Hanna, Alaa Houri, and Bonnie Klimes-Dougan. 2012. Protective functions of religious traditions for suicide risk. Suicidology Online 3: 59-71.

Pargament, Kenneth I. 1997. The Psychology of Religion and Coping. New York: Guilford Press.

Pargament, Kenneth I. 2007. Spiritually Integrated Psychotherapy: Understanding and Addressing the Sacred. New York: Guilford Press.

Pargament, Kenneth I., Annette Mahoney, Edward P. Shafranske, Julie J. Exline, and James W. Jones. 2013a. From research to practice: Toward an applied psychology of religion and spirituality. In APA Handbook of Psychology, Religion, and Spirituality (Vol. 2: An Applied Psychology of Religion and Spirituality). Edited by Kenneth I. Pargament, Annette Mahoney and Edward P. Shafranske. Washington, DC: American Psychological Association, pp. 3-22.

Pargament, Kenneth I., Annette Mahoney, Julie J. Exline, James W. Jones, and Edward P. Shafranske. 2013b. Envisioning an integrative paradigm for the psychology of religion and spirituality. In APA Handbook of Psychology, Religion, and Spirituality (Vol. 1: Context, Theory, and Research). Edited by Kenneth I. Pargament, Julie. J. Exline and James W. Jones. Washington, DC: American Psychological Association, pp. 3-19.

Pargament, Kenneth I., Melissa D. Falb, Gene G. Ano, and Amy B. Wachholtz. 2013c. The religious dimension of coping: Advances in theory, research, and practice. In Handbook of the Psychology of Religion and Spirituality, 2nd ed. Edited by Raymond F. Paloutzian and Crystal L. Park. New York: Guilford Press, pp. 560-79.

Pargament, Kenneth I., Kavita M. Desai, and Kelly M. McConnell. 2014. Spirituality: A pathway to posttraumatic growth or decline? In Handbook of Posttraumatic Growth: Research and Practice. Edited by Lawrence G. Calhoun and Richard G. Tedeschi. New York: Psychology Press, pp. 121-37.

Pargament, Kenneth I., Serena Wong, and Julie J. Exline. 2016. Wholeness and holiness: The spiritual dimension of eudaimonics. In Handbook of Eudaimonic Well-Being. Edited by Joar Vittersø. Cham: Springer International, pp. 379-94.

Park, Crystal L., and Jeanne M. Slattery. 2013. Religion, spirituality, and mental health. In Handbook of the Psychology of Religion and Spirituality, 2nd ed. Edited by Raymond F. Paloutzian and Crystal L. Park. New York: Guilford Press, pp. 540-59.

Pew Research Center. 2011. Global Christianity-A Report on the Size and Distribution of the World's Christian Population. Available online: https:/ /www.pewforum.org/2011/12/19/global-christianity-exec/ (accessed on 30 September 2021).

Piedmont, Ralph L., Jesse Fox, and Marion E. Toscano. 2020. Spiritual crisis as a unique causal predictor of emotional and characterological impairment in atheists and agnostics: Numinous motivations as universal psychological qualities. Religions 11: 551. [CrossRef] 
Plath, Sylvia. 1992. Lady Lazarus. In Collected Poems. New York: HarperCollins. First published 1960.

Plöderl, Martin, Sabine Kunrath, and Clemens Fartacek. 2020. God bless you? The association of religion and spirituality with reduction of suicide ideation and length of hospital stay among psychiatric patients at risk for suicide. Suicide and Life-Threatening Behavior 50: 95-110. [CrossRef] [PubMed]

Prempeh, Henry. 2013. African American Adolescent Suicide: Anger, Religious Coping Style, and Suicidal Behavior. Ph.D. dissertation, The George Washington University, Washington, DC, USA. ProQuest number 3593328.

Raines, Amanda M., Kathryn S. Macia, Joseph M. Currier, Sidonia E. Compton, Chelsea R. Ennis, Joseph I. Constans, and C. Laurel Franklin. 2020. Spiritual struggles and suicidal ideation in veterans seeking outpatient treatment: The mediating role of perceived burdensomeness. Psychology of Religion and Spirituality. Advance online publication. [CrossRef]

Rickgarn, Ralph L. V. 1990. Risk assessment of the suicidal religious person: Some suggestions. Counseling and Values 35: 73-76. [CrossRef]

Rosmarin, David H., Joseph S. Bigda-Peyton, Dost Öngur, Kenneth I. Pargament, and Thröstur Björgvinsson. 2013. Religious coping among psychotic patients: Relevance to suicidality and treatment outcomes. Psychiatry Research 210: 182-87. [CrossRef]

Schneiders, Sandra M. 2011. Approaches to the study of Christian spirituality. In The Blackwell Companion to Christian Spirituality. Edited by Arthur Holder. Chichester: Wiley-Blackwell, pp. 15-34.

Shannonhouse, Laura R., Jordan D. Snyder, Matthew Fullen, Edward B. Davis, Stacey E. McElroy-Heltzel, Mary Chase Breedlove Mize, Jamie D. Aten, Don E. Davis, Joshua N. Hook, and Daryl R. Van Tongeren. 2020. Resource loss, religious coping, and suicide predictors/outcomes during the COVID-19 pandemic: A prospective study of U.S. racially diverse older adults. Journal of Psychology \& Christianity 39: 313-27.

Shneidman, Edwin S. 1993. Suicide as Psychache: A Clinical Approach to Self-Destructive Behavior. Northvale: Jason Aronson.

Shneidman, Edwin S. 1996. The Suicidal Mind. New York: Oxford University Press.

Shore, Peter. 2007. Suicidology: An Oral History. Ph.D. dissertation, The Chicago School of Professional Psychology, Chicago, IL, USA. ProQuest number 3347716.

Smigelsky, Melissa A., Charles Jardin, Jason A. Nieuwsma, Mira Brancu, Keith G. Meador, Kiera G. Molloy, VA Mid-Atlantic MIRECC Workgroup, and Eric B. Elbogen. 2020. Religion, spirituality, and suicide risk in Iraq and Afghanistan era veterans. Depression and Anxiety 37: 728-37. [CrossRef] [PubMed]

Stack, Steven. 1983. The effect of religious commitment on suicide: A cross-national analysis. Journal of Health and Social Behavior 24: 362-74. [CrossRef] [PubMed]

Stack, Steven, and Augustine J. Kposowa. 2011. Religion and suicide acceptability: A cross-national analysis. Journal for the Scientific Study of Religion 50: 289-306. [CrossRef]

Stack, Steven, and Frederique Laubepin. 2019. Religiousness as a predictor of suicide: An analysis of 162 European regions. Suicide and Life-Threatening Behavior 49: 371-81. [CrossRef]

Sveticic, Jerneja, and Diego De Leo. 2012. The hypothesis of a continuum in suicidality: A discussion on its validity and practical implications. Mental Illness 4: 73-78. [CrossRef] [PubMed]

Swinton, John. 2001. Spirituality and Mental Health Care: Rediscovering a 'Forgotten' Dimension. London: Jessica Kingsley.

Townsend, Loren L. 2006. Suicide: Pastoral Responses. Nashville: Abingdon Press.

United Church of Christ [UCC] Mental Health Network. 2021. Becoming WISE. Available online: https://www.mhn-ucc.org/ becoming-wise/ (accessed on 13 August 2021).

Vieten, Cassandra, Shelley Scammell, Alan Pierce, Ron Pilato, Ingrid Ammondson, Kenneth I. Pargament, and David Lukoff. 2016. Competencies for psychologists in the domains of religion and spirituality. Spirituality in Clinical Practice 3: 92-114. [CrossRef]

Webb, Christine. 1992. The use of the first person in academic writing: Objectivity, language and gatekeeping. Journal of Advanced Nursing 17: 747-52. [CrossRef] [PubMed]

Webb, David. n.d. Bringing Self and Soul into Suicidology. Thinking about Suicide (blog). Available online: https:// thinkingaboutsuicide.org/integral-suicidology/ (accessed on 1 August 2021).

Whalley, Elsa A. 1964. Religion and suicide. Review of Religious Research 5: 91-110. [CrossRef]

White, Jennifer. 2016. Qualitative evidence in suicide ideation, attempts, and suicide prevention. In Handbook of Qualitative Health Research for Evidence-Based Practice. Edited by Karin Olson, Richard A. Young and Izabela Z. Schultz. New York: Springer, pp. 335-54.

Wittkowski, Joachim, Kenneth J. Doka, Robert A. Neimeyer, and Michael Vallerga. 2015. Publication trends in thanatology: An analysis of leading journals. Death Studies 39: 453-62. [CrossRef] [PubMed]

World Health Organization [WHO]. 2019. Suicide: One Person Dies Every 40 Seconds. Available online: https: / /www.who.int/news / item/09-09-2019-suicide-one-person-dies-every-40-seconds (accessed on 10 August 2021).

World Health Organization. 2021. Suicide. Last modified 17 June 2021. Available online: https:/ /www.who.int/en/news-room/factsheets/detail/suicide (accessed on 10 August 2021).

Zhang, Jie, and Huilan Xu. 2007. The effects of religion, superstition, and perceived gender inequality on the degree of suicide intent: A study of serious attempters in China. OMEGA-Journal of Death and Dying 55: 185-97. [CrossRef] 